\title{
PELAKSANAAN KURIKULUM 2013 PADA MATA PELAJARAN SEJARAH DALAM PEMBENTUKAN KARAKTER SISWA DI SMP 38 PADANG
}

\author{
Meldawati \\ Email : Anifhanifa380@gmail.com
}

\begin{abstract}
Abstrak
Penulisan ilmiah ini adalah temuan dari penulisan tentang Implementasi Kurikulum 2013 dalam mata pelajaran sejarah untuk membangun karakter siswa kelas IX Di Sekolah Menengah Pertama Negeri 38 Padang, yang menjadi latar belakang penulisan ini. situasi di mana sebagian siswa masih belum dapat menunjukkan karakter yang menuntut dalam kehidupan sehari-hari, yang terdiri dari nilai-nilai spiritual dan nilai-nilai sosial. Penelitian ini menggunakan metode survey dengan pengumpulan data melalui angket, observasi dan wawancara.Setelah data dianalisis, hasil dalam nilai-nilai spiritual, siswa mulai menunjukkan dan mempraktikkan pengajaran agama dengan baik dengan kategori tinggi dan dalam nilai-nilai sosial, siswa menunjukkan karakter seperti kejujuran, disiplin, tanggung jawab, toleransi, kerja sama, sopan dan percaya diri oleh kategori tinggi. Dapat disimpulkan bahwa, Implementasi Kurikulum 2013 dalam mata pelajaran Sejarah khususnya dalam pembangunan karakter berjalan dengan efektif dan efisien, meskipun masih ditemukan kelemahan dan hambatan dalam implementasi.
\end{abstract}

Kata Kunci : Kurikulum 2013, Mata pelajaran sejarah, Pembentukan karakter, Siswa

\section{Pendahuluan}

Pengembangan kurikulum2013 merupakan bagian dari strategi meningkatkan pencapaian pendidikan. Disamping kurikulum, terdapat sejumlah factor diantaranya: lama siswa bersekolah, pembelajaran siswa aktif berbasis kompetensi, buku pegangan atau buku babon dan peranan guru sebagai ujung tombak pelaksanaan pendidikan. Pengembangan kurikulum2013 diorientasikan terjadi peningkatan dan keseimbangan antara kompetensi sikap (attitude), keterampilan (skill), dan pengetahuan (knowledge). Hal ini sejalan dengan amanat UU No.20 tahun 2003 dalam Abdul Majid (2014:37) sebagaimana tersurat dalam penjelasan pasal 35: kompetensi lulusan merupakan kualifikasi kemampuan lulusan yang mencakup sikap, pengetahuan dan keterampilan sesuaidengan Standar Nasional yang telah disepakati(Abdul Majid. 2014 :37).

Kurikulum 2013 pada Sekolah Menengah Pertama dikembangkan atas dasar teori "pendidikan berdasarkan standar" dan teori kurikulum berbasis kompetensi 
Pendidikan berdasarkan standar adalah pendidikan yang menetapkan standar nasional sebagai kualitas minimal warga Negara untuk suatu jenjang pendidikan. Standar bukan kurikulum dan kurikulum dikembangkan agar peserta didik mampu mencapai kualitas Standar Kompetensi Lulusan. Standar Kompetensi Lulusan ini dikembangkan menjadi Standar KompetensiLulusan satuan pendidikan SKL SD/MI, SMP/MTS, SMA/MA, SMK/MAK (dalam Abdul Majid. 2014 :40).

Kompetensi adalah kemampuan seseorang untuk bersikap, menggunakan pengetahuandan keterampilan untuk melaksanakan suatu tugas disekolah, masyarakat dan lingkungan.Kurikulum berbasis kompetensi dirancang untuk memberikan pengalaman belajar seluas- luasnyabagipesertadidik untuk mengembangkan sikap, keterampilan dan pengetahuan yang dikembangkan dalam SKL yang harus dimiliki oleh peserta didik pada setiap tingkat kelas dan program. (dalam Abdul Majid. 2014 :40). $\mathrm{KI}^{1}$ dan $\mathrm{KI}^{2}$ termasuk dalam ranah afektif yang berkaitan dengan kemampuan dan penguasan segi-segi emosional, sikap dan nilai, sedangkan $\mathrm{KI}^{3}$ adalah ranah kognitif berkaitan dengan kemampuan dan kecakapan-kecakapan intelektual, dan $\mathrm{KI}^{4}$ yaitu ranah psikomotor berkaitan dengan keterampilan-keterampilan yang diperoleh oleh peserta didik.

Kompetensi sikap Spritual dan sikap Sosial, dicapai melalui pembelajaran tidak langsung (indirect teaching) yaitu keteladanan, pembiasaan, dan budaya sekolah memperhatikan karakteristik mata pelajaran serta kebutuhan kondisi peserta didik. Penumbuhan dan pengembangan sikap dilakukan sepanjang proses pembelajaran berlangsung dan digunakan sebagai pertimbangan guru dalam mengembangkan karakter peserta didik.

Berdasarkan hasil observasi awal yang dilakukan di SMPN 38 Padang sekolah yang memakai kurikulum2013, kurikulum 2013 di SMP lebih menekankan pada keterampilan atau soft skill pada peserta didik. Kemudian menekankan sikap spritual seperti kegiatan sholat berjamaah namun siswa tidak dibiasakan melakukan sholat berjamaah. Sementara $\mathrm{KI}^{2}$ berkaitan dengan sikap social pada kurikulum 2013 seperti siswa terlambat masuk kelas, cabut pada saat jam pelajaran dan tidak hadir tanpa keterangan, maka kedisiplinan siswa kurang untuk mematuhi peraturan yang telah ditetapkan oleh sekolah. Berdasarkan latar belakang 
diatas, maka penulis tertarik dengan judul "Pelaksanaan Kurikulum 2013 pada Mata Pelajaran Sejarah Dalam Pembentukan Karakter Siswa SMPN 38 Padang”.Berdasarkan latar belakang diatas diatas, maka rumusan masalah dalam penelitian ini adalah: Bagaimanakah sikap spritual dan social yang menunjukkan prilaku jujur, disiplin, tanggung jawab, toleransi, gotong royong, santun dan sopan, serta percaya diri peserta didik yang berhubungan dengan KI1 dan $\mathrm{KI}^{2}$ pada mata pelajaran sejarah di SMPN 38 Padang. Tujuan penulisan ini mendiskripsikan sikap spritual dan social dengan menunjukkan prilaku jujur, disiplin, tanggungjawab, toleransi, gotong royong, sopan dan santun serta percaya diri peserta didik yang berhubungan dengan K1 2 pada mata pelajaran sejarah di SMPN 38 Padang.

\section{Metode Penelitian}

Jenis metode dalam penulisan ini adalah bersifat deskriptif kuantitatif, karena penulis hanya ingin menggambarkan bagaimana pelaksanaan pendidikan Karakter di SMPN 38 Padangyang terkait dengan KI 1 dan KI2 yaitu sikap Spritual dan sosial. Selain itu untuk pengumpulan data dipakai disebarkan angket pada peserta didik terkait aspek sosial dari KI2.

Informan penelitian adalah orang yang dimanfaatkan untuk memberikan Informasi tentang situasi dan kondisi penelitian, sebagai anggota masyarakat dengan kebaikan dan kesuka relaan dia dapat memberikan pandangan tentang nilai, sikap dan kebudayaan (Maleong, 2010 :132). Teknik pemilihan informan adalah sampling purposive adalah teknik penentuan sampel dengan pertimbangan tertentu (Sugiyono, 2011 : 124) upaya untuk mendapat data maka informan pada penulisan ini adalah kelas IX ditambah dengan keterangan waka kurikulum, guru mata pelajaran sejarah. Teknik pengumpulan data melalui angket, observasi dan wawancara.

\section{Hasil Dan Pembahasan}

Kelas IX E berjumlah 26 orang .berdasarkan hasil pengamatan dilapangan bahwa siswaselalu berdoa sebelum dan sesudah memulai pelajaran, agar kegiatan pembelajaran berjalan dengan baik dan pelajaran yang dipelajari dapat dipahami dengan mudah oleh peserta didik. Kemudian yang diamati yaitu mengucapkan salam, siswa selalu mengucapkan salam kepada guru mata pelajaran sebelum dan sesudah memulai pelajaran. Pada sikap spritual ada 2 aspek yaitu ,berdoa, mengucapkan salam sebelum memulai pelajaran. Sementara Karakter 491 | Seminar Nasional Sejarah ke 4 Jurusan Pendidikan Sejarah Universitas Negeri Padang 
dalam setiap sikap sosial memiliki indikator, kemudian indikator tersebut dijadikan sebagai titik tolak untuk menyusun item-item instrumen yang dapat berupa pernyataan atau pertanyaan dengan memberikan tanda cheklist $(\sqrt{ })$ dari sifat positif hingga negatif. Kriteria pemberian skor untuk setiap item pertanyaan atau per indikator sebagai berikut: (1) skor 4 untuk jawaban selalu, (2) skor 3 untuk jawaban Sering, (3) skor 2 untuk jawaban kadang- kadang, (4) skor 1 untuk jawaban tidak pernah.

Angket yang penulis bagikan kepada peserta didik ada 2 macam yaitu :Penilaian diri yang di isi oleh peserta didik itu sendiri. Penilaian diri diisi oleh teman sejawat. Sikap social yaitu: (1) jujur, (2)disiplin, (3) tanggungjawab, (4) toleransi, (5) gotong royong, (6) sopan dan santun, (7) percaya diri. Nilai tertinggi $92,3 \%$ dan nilai terendah 7,69\%.

Tabel:Distribusi frekuensi Lembar Penilaian Diri Sikap Sosial Peserta Didik Kelas I X E

\begin{tabular}{|l|l|l|l|l|}
\hline No & Rentang Skor & Frekuensi & Persentase (\%) & Kategori \\
\hline 1. & $X>152$ & 0 & $0 \%$ & Sangat Tinggi \\
\hline 2. & $114 \leq X<152$ & 24 & 92,3 & Tinggi \\
\hline 3. & $76 \leq X<114$ & 2 & 7,69 & Rendah \\
\hline $4 . S$ & $X<76$ & 0 & $0 \%$ & Sangat Rendah \\
\hline Jumlah & 26 & $100 \%$ & \\
\hline
\end{tabular}

uSumber: Data Olahan Sendiri

Rentang skor sikap social yang di isi oleh peserta didik itu sendiri terdiri dari 2 rentang skor, rentang $114 \leq X<152$ sebanyak 24 dengan kategori sangat tinggi,dan rentang skor $76 \leq X<114$ sebanyak 2 orang

Gambar: Diagram Lembaran Penilaian Diri Sikap Sosial peserta didik kelas IX E 


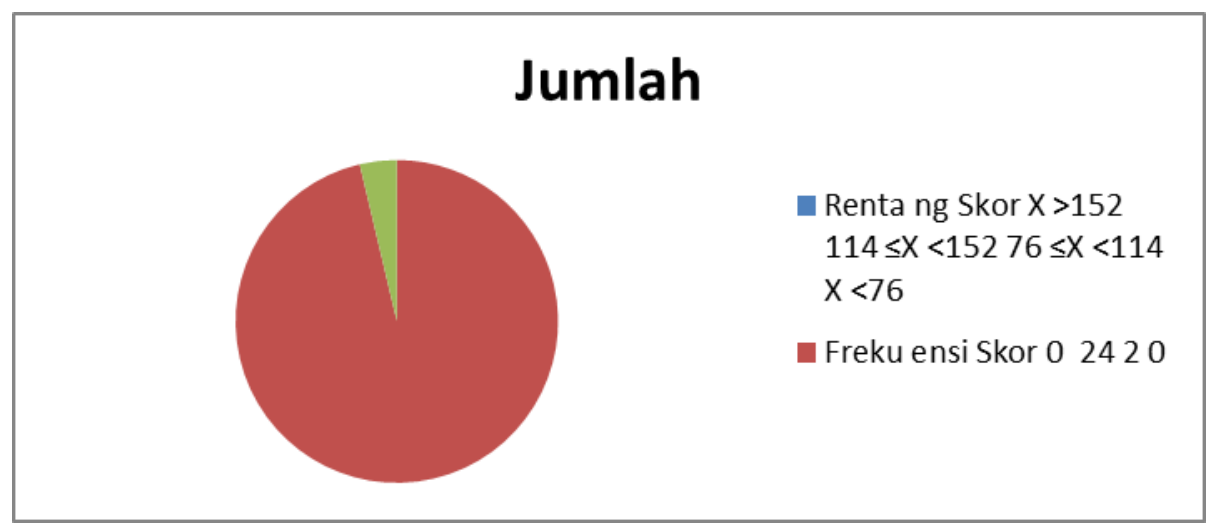

Sumber:olahan sendiri

Kategori pada pembahasan di atas dapat dijelaskan melalui diagram dengan persentase 92,3\% nilai tertinggi, dan 7,69 nilai terendah jika dijumlahkan hasilnya 100\%. Berdasarkan diagramatas bahwa siswa kelas IX sudah menunjukkan prilaku jujur, disiplin, tanggung jawab, toleransi, gotong royong, sopan dan santun dan percaya diri sudah tergolong tinggi, maka karakter peserta didik dapat dikatakan Baik karena9 2\% ini adalah siswa yang mempunyai karakter baik serta kurikulum 2013 yaitu sikap sosial sudah berjalan sesuai dengan tuntutan 2013 di SMP N 38 Padang.

Distribusi frekuaensi sikap sosial diantaranya yaitu 1) jujur, (2) disiplin, (3) tanggung jawab, (4) toleransi, (5) gotong royong, (6) sopan dan santun, (7) percaya diri. Nilai tertinggi 80,76\% dan nilai terendah $19,23 \%$.

Tabel :Distribusi Frekuensi SikapSosial Penilaian Antar Teman Kelas IX E

\begin{tabular}{|l|l|l|l|l|}
\hline No & Rentang Skor & Frekuensi & $\begin{array}{l}\text { Persentase } \\
(\%)\end{array}$ & Kategori \\
\hline 1. & $\mathrm{X}>152$ & 0 & 0 & Sangat Tinggi \\
\hline 2. & $114 \leq \mathrm{X}<152$ & 21 & 80,76 & Tinggi \\
\hline 3. & $76 \leq \mathrm{X}<114$ & 5 & 19,23 & Rendah \\
\hline 4. & $\mathrm{X}<76$ & 0 & 0 & Sangat Rendah \\
\hline
\end{tabular}

Sumber: Data Olahan Sendiri

Rentang skor sikap social yang di isi oleh peserta didik itu sendiri terdiri dari 493 | Seminar Nasional Sejarah ke 4 Jurusan Pendidikan Sejarah Universitas Negeri Padang 
2 rentang skor, rentang $114 \leq \mathrm{X}<152$ sebanyak 21 orang dengan kategori tinggi, dan rentang skor $76 \leq X<114$ dengan kategori rendah sebanyak 5 orang, jadiKesimpulan nilai sikap sosial antar peserta didik dengan kategori tinggi.

Gambar :DiagramPenilaian Sikap Sosial Antar Peserta Didik kelas IX

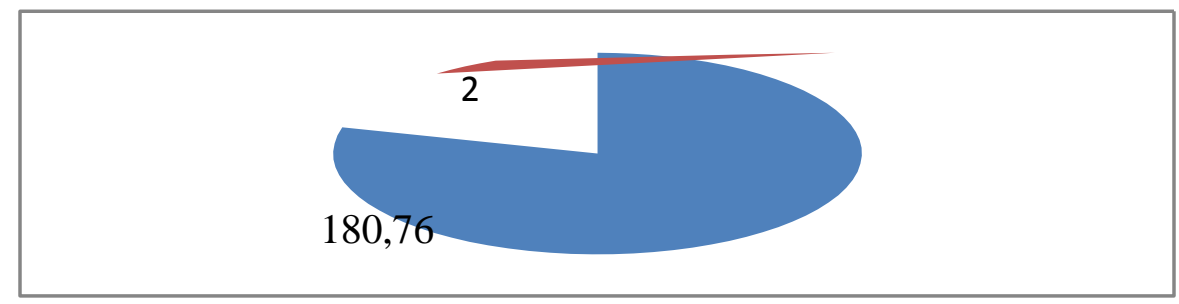

Sumber: Olahan Data Sendiri

Kategori pada pembahasan di atas dapat dijelaskan melalui diagram dengan persentase 80,76 nilai tertinggi, dan 19,23\% nilai terendah jika dijumlahkan hasilnya 100\%. Berdasarkan diagramdi atas, sikap sosial peserta didik penilaian yang diisi oleh individu itu sendiri, dan penilaian antar teman menunjukkan bahwa siswa IX E SMP N 38 Padang dengan kategori tinggi.

\section{Keterkaitan Mata Pelajaran Sejarah Terhadap Pembentukan Karakter}

Melalui kurikulum2013, silabus dari guru mata pelajaran sejarah, dan wawancara bahwa sikap spiritual dan sikap social pada peserta didik selain dilakukan pembiasaan oleh guru mata pelajaran juga ditanamkan atau diajarkan pada setiap materi mata pelajaran sejarah.

\section{Simpulan}

Sikap spiritual peserta didik kelas IXdengan kategori tinggi. BerdasarkanTeknik pengumpulandata melalui observasi, angket, wawancara dan dokumen maka hasil sikap peserta didik dalam sikap spiritual yaitu berdoa, mengucapkan salam Siswa selalu berdoa sebelum belajar, mengucapkan salam kepada guru mata pelajaran, hal ini sesuai dengan tuntutan Kurikulum 2013 dalam ranah $\mathrm{KI}^{1}$ yaitu Spritual yang berbunyi: "menghayati dan mengamalkan ajaran agama yang dianutnya" Artinya siswa sudah mengamalkannya dengan baik dan dengan kategori sangat tinggi.

494 | Seminar Nasional Sejarah ke 4 Jurusan Pendidikan Sejarah Universitas Negeri Padang 
Lembar Penilaian Diri Sikap Sosial peserta didik adalah penilaian yang di isi oleh peserta didik itu sendiri, berdasarkan penyajian data melalui diagram diperoleh persentase peserta didik terbanyak 92\%, diperoleh melalui distribusi frekuensi dengan rentang skor $114 \leq$ $\mathrm{X}<152$ dengan frekuensi 22, maka 92\% ini merupakan kategori tinggi. Lembar Penilaian Antar Teman Sikap Sosial Peserta Didik Adalah penilaian antar teman yang di isi oleh teman sebangku, hal ini dikarenakn teman sebangku lebih paham dan mengetahuiKarakter masingmasing peserta didik, ditambah lagi sudah satu kelas sejak kelas VIII. Berdasarkan penyajian data melalui diagram diperoleh persentase peserta didik terbanyak $80 \%$, diperoleh dari distribusi frekuensi dengan rentang skor skor $114 \leq \mathrm{X}<152$ dengan frekuensi 19 dengan kategori tinggi.

Berdasarkan 2 aspek penilaian tersebut dapat disimpulkan bahwa sikap social peserta didik kelas IX E dengan kategori tinggi. Peserta didik kelas XI sudah menunjukkan prilaku Jujur, Disiplin, Tanggung Jawab, Peduli, Gotong Royong, Sopan dan Santun, dan Percaya Diri dengan kategori tinggi. Kesimpulan dari 7 aspek sikap sosial yang berbunyi "menunjukkan prilaku Jujur, Disiplin, Tanggung Jawab, Toleransi, Gotong Royong, Sopan atau santun, dan Percaya diri sebagai bagian atas berbagai permasalahan dalam berinteraksi secara efektif dalam lingkungan social dan alam serta menempatkan diri sebagai cerminan bangsa dalam pergaulan sehari-hari" sudah tertanam melalui mata pelajaran sejarah dan berperan dalam pembentukan karakter siswa.

\section{DAFTAR PUSTAKA}

Abdul, majid.2014. Implementasi Kurikulum2013.Bandung: Interes Media Morissan, dkk. 2012.Metode Penelitian Survai.Jakarta: KencanaPrenada MediaGrup.

Sugiyono.2011. Metode Penelitian Pendidikan. Bandung :Alfabeta Maleong,.Lexy J. 2010. Metode Penelitian Kualitatif. Bandung: Rosdakarya. Juli Mardayanti, 2018, Pelaksanaan Kurikulum 2013Pada Mata Pelajaran Sejarah Dalam Pembentukan Karakter Siswa Di SMK Negeri 1Koto baru Kabupaten Dharmasraya, STKIP PGRI Sumatera Barat 